https://doi.org/10.19195/0080-3626.63.8

DAWID SULIKOWSKI

\title{
DZIAŁALNOŚĆ KULTURALNO-OŚWIATOWA CHIŃSKICH BIBLIOTEK PUBLICZNYCH NA PRZYKŁADZIE BIBLIOTEK W SZANGHAJU, XICHANG I CHENGDU
}

Zasady organizacji bibliotek publicznych w Chinach i ich działalność kulturalno-oświatowa. Wschodni Oddział Szanghajskiej Biblioteki Publicznej. Biblioteka Publiczna w Xichang. Biblioteka Prowincji Syczuan w Chengdu.

SŁOWA KLUCZOWE: bibliotekarstwo publiczne, Chiny, Szanghaj, Xichang, Chengdu

Problematyka współczesnego bibliotekarstwa chińskiego bardzo rzadko gości na łamach polskich czasopism bibliologicznych i bibliotekoznawczych. Jest to tym bardziej rażące, że mamy w tym wypadku do czynienia z jednym z największych i najbardziej dynamicznie rozwijających się państw na świecie, a co za tym idzie także dynamicznie rozwijającym się tamtejszym bibliotekarstwem publicznym, a zwłaszcza realizowaną przez nie działalnością kulturalno-oświatową. Dlatego też celem niniejszego artykułu jest zaznajomienie polskiego czytelnika z tą problematyką przez przedstawienie na trzech wybranych przykładach: Wschodniego Oddziału Szanghajskiej Biblioteki Publicznej, Biblioteki Publicznej w Xichang i Biblioteki Prowincji Syczuan w Chengdu ogólnego obrazu działalności kulturalno-oświatowej tego segmentu bibliotek we współczesnych Chinach. Warto w tym miejscu wyjaśnić, że okazją do zaznajomienia się autora z problematyką bibliotekarstwa publicznego w Chinach jest jego dłuższy pobyt w mieście Xichang w prowincji Syczuan, gdzie od kilku lat prowadzi szkołę malarską dla dzieci, a okazją do napisania tego tekstu - studia na kierunku informacja naukowa i bibliotekoznawstwo na Uniwersytecie Wrocławskim ${ }^{1}$. Głównymi źródłami informacji przy pisaniu artykułu, stanowiącymi jego merytoryczną podstawę, były strony internetowe, na których znajdują się naukowe artykuły traktujące o tym temacie,

${ }^{1}$ Artykuł powstał na podstawie pracy magisterskiej Biblioteki publiczne w Chińskiej Republice Ludowej. Struktura organizacyjna i działalność (na wybranych przykładach), napisanej w 2019 roku pod kierunkiem dr hab. prof. UWr Bożeny Koredczuk.

ROCZNIKI BIBLIOTECZNE ROCZNIKI BIBLIOTECZNE, R. LXIII: 2019

ROK LXIII, 2019

(C) for this edition by CNS 
a także oficjalne portale konkretnych bibliotek publicznych. Istotnymi źródłami informacji na temat bibliotek publicznych były również anglojęzyczne publikacje książkowe oraz specjalistyczne wydawnictwa z zakresu bibliotekoznawstwa. Ze względu na przebywanie w Chinach i możliwość utrzymywania prywatnych kontaktów z pracownikami tamtejszych bibliotek ważnym źródłem informacji stały się przeprowadzone $\mathrm{z}$ nimi wywiady.

\section{ZASADY ORGANIZACJI BIBLIOTEK PUBLICZNYCH I ICH DZIAŁALNOŚCI KULTURALNO-OŚWIATOWEJ}

Biblioteki publiczne w Chińskiej Republice Ludowej są — obok bibliotek akademickich (edukacyjnych) i bibliotek badawczych (naukowych) — jednym $\mathrm{z}$ trzech głównych segmentów tamtejszego bibliotekarstwa ${ }^{2}$. Tworzą one osobną sieć, koordynowaną i zarządzaną centralnie przez właściwe organy administracji państwowej, ustanowione wraz z przejęciem w 1949 roku władzy w Chinach przez Komunistyczną Partię Chin - obecnie rolę tę pełni Wydział Biblioteczny Ministerstwa Kultury ChRL ${ }^{3}$.

Sieć bibliotek publicznych ma strukturę hierarchiczną — na ich czele znajduje się Chińska Biblioteka Narodowa, która pełni funkcję repozytorium całości literatury chińskiej, tworzy narodowe centrum bibliograficzne, a także krajowe centrum ochrony i konserwacji dawnej książki. Poza swą podstawową, ściśle biblioteczną, działalnością prowadzi również badania w dziedzinie bibliotekoznawstwa, wspiera rozwój bibliotekarstwa oraz udziela porad i wskazówek innym bibliotekom w Chinach ${ }^{4}$. Oprócz niej omawianą sieć tworzą biblioteki prowincjonalne, miejskie, prefekturalne i niższych szczebli ${ }^{5}$. Do grupy tej należą także biblioteki przeznaczone dla specjalnej grupy odbiorców, to jest biblioteki dziecięce oraz etniczne, stworzone z myślą o mniejszościach narodowych. W 2018 roku w Chinach funkcjonowało 3176 bibliotek publicznych, zaspokajających potrzeby około 1,4 miliarda mieszkańców tego państwa. Warto jednak zaznaczyć, że tempo powstawania tych placówek nabrało rozmachu dopiero po przemianach polityczno-ekonomicznych zainicjowanych w Chinach przez ekipę Deng Xiaopinga w 1976 roku. Tylko w ciągu dwóch lat (1977-1979) ich liczba została podwojona (z $851 \mathrm{w} 1977$ roku do $1732 \mathrm{w} 1980$ ), a na początku XXI wieku osiągnęła ona 2700 placówek. W aktualnych planach Komunistycznej Partii Chin uwzględniane jest dalsze zakładanie nowych bibliotek ${ }^{6}$.

2 S. Chien Lin, Libraries and Librarianship in China, Westport 1998, s. 46.

3 http://1l.china-embassy.org/eng/whys/whzc/t159977.htm [dostęp: 5.05.2019].

4 http://www.nlc.cn/newen/ [dostęp: 5.05.2019].

5 http://il.china-embassy.org/eng/whys/whzc/t159977.htm [dostęp: 5.05.2019].

${ }^{6}$ Z. Yi, History of Library Developments in China, http://library.ifla.org/143/1/164-yi-en. pdf [dostęp: 15.10.2019]; http://news.voc.com.cn/article/201906/201906111645587066.html [dostęp: 10.11.2019]. 
W ich strukturze organizacyjnej ${ }^{7}$ najważniejszą rolę odgrywa zakładowa organizacja partyjna Komunistycznej Partii Chin. W zależności od wielkości placówki może być to komitet partyjny, oddział lub grupa partyjna. Głównym zadaniem organizacji partyjnej jest przywództwo polityczne i ideologiczne w bibliotece. Nadzoruje ona realizowanie prac bibliotecznych zgodnie z wyznaczonymi dyrektywami partyjnymi i wymogami ideologicznymi. Organizacja partyjna ma również rozstrzygający głos przy podejmowaniu najważniejszych decyzji w sprawach bibliotecznych. Kierowanie pracami całej struktury administracyjnej biblioteki spoczywa w gestii Biura Kustosza - organ ten składa się z kustosza i dyrektora biblioteki oraz ich zastępców. Kustoszowi biblioteki podlega komitet biblioteczny. W jego skład wchodzą dyrektorzy, zastępcy dyrektorów, sekretarze i ich zastępcy oraz dyrektorzy (kierownicy) poszczególnych departamentów (działów) bibliotecznych. Zadaniem komitetu bibliotecznego jest podejmowanie decyzji w najważniejszych sprawach dotyczących działalności biblioteki, z wyjątkiem tych, które wymagają zatwierdzenia przez kustosza biblioteki ${ }^{8}$.

Działalność biblioteczna leży w gestii tak zwanych agencji operacyjnych, których organizacja nie odbiega od zasad wypracowanych powszechnie w bibliotekarstwie, związanych z gromadzeniem, opracowaniem, udostępnianiem i informowaniem o zbiorach. W kontekście działalności kulturalno-oświatowej ważna jest rola działów referencyjnych (doradztwa), które zajmują się organizacją i prowadzeniem bibliografii tematycznych, udzielają także użytkownikom biblioteki wszelkich informacji ułatwiających im korzystanie ze zbiorów i usług biblioteki, również w formie bezpłatnych konsultacji. Działy te dynamicznie rozwijają swoją działalność ze względu na konieczność nadążania za zmianami w sferze technologii informacyjnych (wyszukiwanie informacji w bazach danych i sieci internetowej) i rosnącymi potrzebami użytkowników ${ }^{9}$. Ważną rolę w tym kontekście odgrywa też dział zastosowań i usług nowoczesnych technologii, odpowiadający za wdrażanie nowych technologii w zakresie reprodukowania zbiorów, komunikacji i informacji naukowej. Istotną funkcję na tym polu pełni kolegialny organ doradczy w postaci stowarzyszenia czytelników, złożonego z przedstawicieli użytkowników biblioteki, którzy w aktywny sposób działają na rzecz ulepszenia jej użyteczności i dostosowania do wymagań środowiska społecznego, w którym funkcjonują. Do głównych zadań tego organu należy udzielanie informacji na temat potrzeb użytkowników oraz jakości pracy pracowników biblioteki, nadzorowanie stosunków między pracownikami a użytkownikami, słuchanie opinii

7 https://wenku.baidu.com/view/ff792d6b58fafab069dc0269.html [dostęp: 5.06.2019].

${ }^{8}$ Li Yongliang, Zhong hua ren min gong he guo gong gong tu shu guan fa shi yi ji cao zuo shi wu [ang. Public Library Law of the People's Republic of China Interpretation and Operation Practice], China Knowledge Publishing House Pekin 2017, s. 64.

${ }^{9}$ Ibidem, s. 65. 
i wychodzenie naprzeciw dezyderatom osób korzystających ze zbiorów bibliotecznych ${ }^{10}$.

Chińskie biblioteki publiczne podejmują różnorodne działania zmierzające do upowszechniania oświaty i kultury, ponieważ aktualnie coraz więcej osób jest przeświadczonych, że kultura i sztuka powinny mieć szczególne miejsce w ich życiu. Dużą rolę odgrywa tutaj nostalgia za tym, co zostało utracone w czasie chińskiej rewolucji kulturalnej (w latach 1966-1976), a także rosnące potrzeby i oczekiwania społeczeństwa w stosunku do oferty bibliotek. W związku z tym placówki nie mogą się już ograniczać wyłącznie do zapewnienia dostępu do informacji, lecz stają się także przestrzenią oferującą użytkownikom możliwość twórczego działania.

Dotyczy to między innymi działalności multimedialnej opartej na aplikacji DiGiBook MakerSpace (DBMS), bazującej na wzorcach europejskich i amerykańskich. Ta kreatywna usługa wyprodukowana przez wiodącą $\mathrm{w}$ tym zakresie firmę Shanghai DiGiBook Ltd. ma w swojej ofercie zupełnie nowe rozwiązania czytelnicze, pozwalające harmonijnie łączyć elektroniczne czytanie z tworzeniem i przechowywaniem dokumentów multimedialnych. W jej ramach wszyscy użytkownicy mogą stać się autorami i twórcami oryginalnych treści w formie multimedialnej. Idea ta rozwija się obecnie bardzo dynamicznie i ma ogromne poparcie ze strony instytucji rządowych — program, wspierany przez Narodowy Fundusz Nauk Społecznych, został w 2014 roku zainstalowany w 30 bibliotekach publicznych. DBMS jest bardzo prosty w obsłudze i dzięki dużym panoramicznym wyświetlaczom dostosowany do potrzeb nawet najstarszych członków rodzin. Ta cyfrowa platforma wydawnicza obejmuje różnorodne zbiory biblioteczne, takie jak książki, fotografie, pliki audiowizualne i inne dokumenty w formie elektronicznej, i dzięki szerokiemu wachlarzowi usług umożliwia wspólną pracę dzieciom i ich najbliższym. Placówki, które posiadają platformę DBMS, stają się warsztatami tworzącymi e-booki i inne formy kreacji artystycznej. Dla usług DBMS przeznaczone są odpowiednie pomieszczenia, dające możliwość czytania i tworzenia własnych pomysłów, oraz właściwej jakości sprzęt elektroniczny. Oprócz zaawansowanych technologicznie urządzeń do przestrzeni twórczej biblioteka oferuje również tradycyjne zabawki edukacyjne, gry planszowe, ale też na przykład sceny do wystąpień najmłodszych. Program DBMS staje się niejako nową formą edukacyjną $\mathrm{w}$ ofercie bibliotek publicznych, które chętnie otwierają się na specjalną grupę użytkowników i są przydatnym narzędziem pomocy w walce z dysleksją. Kolekcje Audio Picture Book Bank, zawierające audiobooki oraz książki cyfrowe z obrazkami, służą polepszeniu poprawnej wymowy, rozumieniu ich treści i właściwemu ich użyciu ${ }^{11}$.

10 Ibidem, s. 68.

11 S. Man et al., Digibook Makerspace in Chinese Public Libraries, 5.03.2014, http://ibrary. ifla.org/826/1/120-shu-en.pdf [dostęp: 12.03.2019]. 
Prorodzinny charakter i ciągłe rozszerzanie usług powodują, że biblioteki publiczne w Chinach wchodzą na nową ścieżkę rozwoju, oferując coraz szerszy wachlarz swych usług. Ukierunkowany jest on głównie na najmłodszych użytkowników wraz z ich najbliższymi, czyniąc bibliotekę instytucją przyjazną i nastawioną na zacieśnianie więzi społecznych. Rodziny stają się priorytetowymi użytkownikami, którzy przez swoją kreatywną działalność umożliwiają placówkom spełniać swe podstawowe funkcje związane z dbaniem i ochroną kultury rodzin i całych lokalnych społeczności ${ }^{12}$.

Zmiany dokonujące się w sferze działalności bibliotek i ich nowych funkcji są przede wszystkim związane z dynamicznym rozwojem nowych technologii, ukierunkowanych na rozwój społeczeństwa informacyjnego oraz coraz bardziej zaawansowanymi wymogami użytkowników. Wszystko to jest przewidziane w planach rozwoju bibliotek, które są omawiane na corocznych zjazdach Kongresu Komunistycznej Partii Chin. Nie są to jednak jedyne wytyczne, których skarbnice wiedzy powinny przestrzegać. Poza zmianami związanymi z nową technologią i jej odpowiednią adaptacją rząd kładzie duży nacisk na artystyczną funkcję bibliotek. Sztuka i kultura, które w czasie rewolucji kulturalnej zostały niemal całkowicie zniszczone przez rewolucyjne rządy Mao Zedonga, przeżywają obecnie renesans. W związku ze zmianami w działalności i celami wyznaczonymi przez właściwe im ministerstwo biblioteki powinny wspomagać promocję kultury i sztuki.

\section{WSCHODNI ODDZIAŁ SZANGHAJSKIEJ BIBLIOTEKI PUBLICZNEJ}

Doskonałym przykładem promowania kultury i sztuki jest Wschodni Oddział Szanghajskiej Biblioteki Publicznej, w którym udostępnianie książek będzie w najbliższym czasie stanowiło tylko znikomą część oferty. Zgodnie z wizją rozwoju tej placówki ma ona być „w niedalekiej przyszłości” wzorcem rozwoju bibliotek publicznych w Chinach. Ich wizytówką mają być przede wszystkim zmiany w funkcji i działalności tych instytucji — biblioteki przyszłości powinny być zorientowane na ludzi, przyjazne dla środowiska, integrujące społeczeństwo, inteligentne i innowacyjne. Nowoczesne rozwiązania architektoniczne, w których pojawiają się sale multimedialne, centra dydaktyczne, kawiarnie, galerie, a także miejsca wypoczynku, mają przyciągać ludzi i stanowić oldenburgowskie ,trzecie miejsce" $" 13$.

Ważnym elementem tych przeobrażeń jest budowa nowego gmachu biblioteki. Ma on być miejscem, gdzie zarówno pojedyncze osoby, jak i grupy użytkowni-

12 Ibidem.

${ }^{13}$ H. Mingrui, Reading books is just one small part of what this library will offer, 25.09.2017, http://www.ecns.cn/2017/09-25/274964.shtml [dostęp: 7.03.2019]. 
ków będą mogły zaspokoić swoje potrzeby społeczne, kulturalne i towarzyskie ${ }^{14}$. Budowa nowego oddziału rozpoczęła się we wrześniu 2017 roku, a jej ukończenie jest planowane na połowę 2020 roku. Jest ona umiejscowiona pomiędzy Szanghajskim Muzeum Nauki i Techniki oraz „Parkiem Wieków”15. Lokalizacja ta nie jest przypadkowa - biblioteka ma bowiem stanowić jedną z części kulturalnego skupiska obiektów w tym rejonie miasta. Budynek biblioteczny został zaprojektowany przez duńską firmę architektoniczną Schmidt Hammer Lassen Architects, która wygrała przetarg na budowę z ponad 15 innymi firmami — głównie dzięki otwartej, przyjaznej i prostej konstrukcji ${ }^{16}$. Projekt zakłada otwartą i przestrzenną powierzchnię biblioteki, liczącą 115 tysięcy metrów kwadratowych i według słów Chen Chao, kustosza tej biblioteki,

jest to projekt zorientowany na ludzi, otwarty i elastyczny, przyjazny dla środowiska. Jednym z powodów, dla których wybieramy ten projekt, jest to, że traktuje on nowoczesną bibliotekę jak miejsce, w którym ludzie mogą pozostać i nawiązywać kontakty społeczne. Budynek będzie stanowił pojedynczy monolit unoszący się nad „baldachimem” drzewa. Po ukończeniu spełni wymagania wszystkich ludzi dotyczących funkcji epokowej biblioteki publicznej ${ }^{17}$.

Słowa te są potwierdzeniem omawianej wcześniej koncepcji socjologicznej Oldenburga, w którym Biblioteka Szanghajska ma być placówką tętniącą życiem, gdzie użytkownicy w aktywny sposób mogą spędzać wolny czas i przez swoją działalność wpływać na jej tożsamość.

Nowoczesna architektura biblioteki zakłada zbudowanie szklanej fasady z przezroczystego, izolowanego szkła. Biblioteka ma sięgnąć siedmiu pięter nad ziemią oraz mieć dwie dodatkowe kondygnacje pod nią. Jej ogromną zaletą jest pojemność - budynek będzie w stanie pomieścić do 6 tysięcy użytkowników, a w skali rocznej placówka będzie mogła obsłużyć 4 miliony osób. Działalność instytucji zakłada również organizację 200 wykładów oraz 2 tysięcy innych wydarzeń kulturalnych w każdym roku. Zbiory biblioteki maja liczyć około 4,8 miliona jednostek ${ }^{18}$.

Ze względu na swoją otwartą konstrukcję nowy gmach Biblioteki Szanghajskiej ma stwarzać integralne połączenie pomiędzy czytelnikami, mediami i otaczającą bibliotekę naturą. Każde piętro stanowi swoistą pod względem merytorycznym i funkcjonalnym przestrzen ${ }^{19}$. Według założeń administracji tej instytucji funkcje starego i nowego gmachu będą się zasadniczo różnić. W głównym gmachu, mieszczącym największą bibliotekę w mieście i drugą co do wielkości w Chinach (ponad 53 milionów jednostek zbiorów), będzie się skupiać prze-

\footnotetext{
14 http://www.sbp.pl/artykul/?cid=9592\&prev=100 [dostęp: 25.05 .2019$]$.

15 https://en.wikipedia.org/wiki/Century_Park_(Shanghai) [dostęp: 7.03.2019].

${ }^{16}$ H. Mingrui, op. cit.

${ }^{17}$ Ibidem; jeśli nie podano inaczej, przeł. D.S.

$18 \mathrm{http}: / /$ narchitects.com/work/shanghai-library/ [dostęp: 7.03.2017].

19 Ibidem.
} 
de wszystkim działalność naukowa ${ }^{20}$. Natomiast Wschodni Oddział będzie przede wszystkim pełnił funkcję publiczną, a poza wypożyczaniem i udostępnianiem zbiorów na miejscu będzie można tu również prowadzić rozmaitą działalność kulturalną. Integracyjny, inteligentny i innowacyjny charakter placówki ma objawiać się w postaci: centrum zasobów, wymiany wiedzy, centrum doświadczeń technologicznych, think tank oraz międzynarodowej platformy komunikacyjnej ${ }^{21}$. Biblioteka będzie także miała pomieszczenia przeznaczone dla dzieci, osób z niepełnosprawnością oraz czytelników w podeszłym wieku — specjalne pawilony będą wyposażone w specjalistyczny sprzęt $\mathrm{i}$ adekwatne do potrzeb określonej grupy użytkowników.

Niezmiernie ciekawym pomysłem, kreującym nową formę i działalność placówki, jest stworzenie pawilonów tematycznych. Pomieszczenia te będą ściśle związane konkretną tematyką, dotyczącą między innymi choreografii, genealogii, sztuki i muzyki. Użytkownicy będą mogli tam czytać, oglądać i uczestniczyć $\mathrm{w}$ interaktywnych zajęciach w celu lepszego zrozumienia interesujących ich lektoratów, mając jednocześnie możliwość własnej kreatywnej wypowiedzi. Usługi te spowodują, że biblioteka będzie centrum nauki dla użytkowników, ukierunkowanym na jej popularyzację. Przez swoją innowacyjną działalność i zaawansowaną technologię instytucja ta ma umożliwiać rozpowszechnienie wiedzy w zakresie dydaktycznym, kulturotwórczym oraz praktycznym ${ }^{22}$.

\section{BIBLIOTEKA PUBLICZNA W XICHANG}

Biblioteka Publiczna w mieście Xichang powstała w 1928 roku $^{23}$, jednak ze względu na toczące się walki między siłami chińskich komunistów a nacjonalistami Kuomintangu Czang Kaj-szeka została tymczasowo zamknięta w 1936 roku $^{24}$. Po objęciu władzy w Chinach przez Komunistyczną Partię Chin bibliotekę ponownie otwarto we wrześniu 1956 roku jako Bibliotekę Prefektury Xichang ${ }^{25}$. Kolejne lata działalności placówki przypadały na okres „rewolucji kulturalnej”. Zgodnie z propagandą chińskiego komunizmu należało całkowicie odciąć się od wszelkich tradycji burżuazyjnych oraz doszczętnie zniszczyć dokumenty i wytwory kultury

${ }^{20} \mathrm{P}$. Wang, Top 10 largest libraries in China, http://www.chinawhisper.com/top-10-largestlibraries-in-china/ [dostęp: 7.03.2019].

21 H. Mingrui, op. cit.

22 http://www.ebib.pl/publikacje/matkonf/biblio21/sesja6ref3.pdf [dostęp: 25.05.2019].

${ }^{23}$ L. Xianghui, Xi Chang tu shu guang ji tu shu shi ye de li shi hui gu yu xian zhuang [ang. Historical review and current situation of Xichang library and book business], [w:] XiChang wen shi, [ang. History of Xichang] red. Y. Liwei, S. Zaide, Z. Yuanchen, Xichang 1993, s. 134.

24 https://pl.wikipedia.org/wiki/Chińska_wojna_domowa [dostęp: 20.05.2019].

${ }^{25}$ L. Xianghui, op. cit., s. 135. 
sprzeczne z nową polityką kulturalną Chińskiej Republiki Ludowej ${ }^{26}$. W wyniku tych działań z placówki zostało usuniętych ponad 100 tysięcy książek, uznanych za pozycje reprezentujące myśli wrogie komunizmowi.

Z zakończeniem „rewolucji kulturalnej” w 1976 roku nadeszły dla biblioteki lepsze czasy. W 1980 roku dzięki nowym lokalnym inwestycjom finansowym (opiewającym na 120 tysięcy juanów) powstał nowy budynek biblioteczny o powierzchni 1020 metrów kwadratowych. Nowy gmach został otwarty dla użytkowników podczas obchodów Chińskiego Nowego Roku w 1982 roku, a po połączeniu sąsiadujących powiatów i miasta w 1986 roku zmieniono nazwę placówki na Bibliotekę Xichang ${ }^{27}$.

W wyniku modernizacji i odnowienia starego miasta biblioteka przeniosła się w grudniu 2016 roku do nowo wybudowanego Centrum Kultury i Sportu. Nowy budynek instytucji ma całkowitą powierzchnię około 4 tysięcy metrów kwadratowych i jest usytuowany na dwóch poziomach. Księgozbiór biblioteki szacuje się obecnie na około 250 tysięcy książek ${ }^{28}$.

Jedną z najczęstszych aktywności kulturalnych tej biblioteki jest organizacja wystaw kaligrafii i malarstwa. Z okazji narodowych festiwali i lokalnych obchodów związanych z tradycją społeczności Yizu placówka współpracuje z Miejskim Muzeum Kultury, Biurem Zarządzania Kulturą oraz Komisją Nauki i Technologii. Zwieńczeniem tej współpracy są cykliczne wystawy nauki i techniki, starego malarstwa i kaligrafii oraz wystawa Narodowej Armii Ludowo-Wyzwoleńczej ${ }^{29}$. Odbywają się one najczęściej w czasie obchodów Chińskiego Nowego Roku, a także Narodowego Święta Chin (tak zwanego złotego tygodnia) związanego z upamiętnieniem powstania Chińskiej Republiki Ludowej 1 października 1949 roku $^{30}$.

Placówka prowadzi również liczne szkolenia i wykłady, mające najczęściej charakter edukacyjny. Są to standardowe zadania z zakresu umiejętności korzystania z biblioteki i zainteresowania czytaniem; pierwsze takie spotkanie odbyło się w 1957 roku w postaci wykładów: Rozwój literatury wprowadzającej do pracy bibliotecznej i Odwotanie do literatury bibliotecznej. Poza tym są tam prowadzone liczne szkolenia dla personelu wojskowego oraz dla pracowników policji prefektury Liangshan, obejmujące naukę hodowli królików czy też techniki uprawy grzybów jadalnych ${ }^{31}$. W ostatnich latach biblioteka wykazuje ponadto dużą aktywność w dziedzinie promocji czytelnictwa wśród najmłodszych - 8 kwietnia 2017 roku odbył się finał pierwszego konkursu czytania dla dzieci „Złoty róg”. Wydarzenie,

${ }^{26}$ Dewastowanie zabytków, niszczenie dziet sztuki, terror. 52 lata temu rozpoczęła się Rewolucja Kulturalna w Chinach, 6.02.2018, http://www.national-geographic.p1/historia/50-lat-temu-rozpoczela-sie-rewolucja-kulturalna-w-chinach [dostęp: 20.05.2019].

27 L. Xianghui, op. cit., s. 137.

28 http://www.xcslib.org/index.php?c=category\&id=23 [dostęp: 20.05.2019].

29 Rozmowa z kustoszem biblioteki Ma Haiyun; badanie własne: 16.05.2019.

${ }^{30}$ https://www.chinahighlights.com/travelguide/china-national-day.htm [dostęp: 20.05.2019].

31 L. Xianghui, op. cit., s. 144. 
odbywające się w czytelni dla dzieci, ma wspierać wzrost zainteresowania tą aktywnością intelektualną ${ }^{32}$. Niespełna miesiąc wcześniej, w marcu tego samego roku, zostało zorganizowane bardzo ciekawe wydarzenie kulturalne. W dniach 25-26 marca placówka zorganizowała zajęcia dla najmłodszych użytkowników pod tytułem ,Świat książki - działania związane z czytaniem i malowaniem przez dzieci". Wydarzenie, w trakcie którego uczestnicy czytali książki i malowali do nich własne ilustracje, dało okazję do kształtowania kreatywności umysłu dzieci, tworzących własne kolorowe woluminy. Dwudniowe weekendowe spotkanie zachęcało również całe rodziny do wspólnej zabawy i spędzania wolnego czasu z najbliższymi, właśnie w „skarbnicy wiedzy”33.

Biblioteka Xichang prowadzi także liczne prace edukacyjne związane $\mathrm{z}$ informacją ludności Yizu o zagrożeniach chorobą AIDS i możliwościach zakażenia się wirusem HIV. Ze względu na bardzo duży problem związany z narkotykami i nosicielstwem przez lokalną społeczność wirusa HIV instytucje publiczne w regionie Liangshan szeroko upowszechniają wiedzę na temat zagrożeń, wspierając ją akcją edukacyjną ${ }^{34}$. Zgodnie z wytycznymi przyjętymi na XIX Kongresie Narodowym Komunistycznej Partii Chin odbywającym się w październiku 2017 roku biblioteki publiczne zostały zobligowane do wdrażania programu „Trzy wiejskie działalności" ${ }^{35}$. Biblioteka Xichang w ramach rozporządzenia rządowego miała pełnić funkcję insty tucji promującej harmonijny rozwój społeczeństwa z okręgów wiejskich. Trzy podstawowe cele to: precyzyjne zmniejszenie ubóstwa, kampania przeciwko narkomanii oraz kampania przeciw AIDS. Jako nadrzędna instytucja biblioteczna prefektury Liangshan instytucja publikowała liczne broszury informacyjne z zakresu wspomnianego programu i dystrybuowała je do bibliotek wiejskich i lokalnych ośrodków kultury. Pracownicy mieli również za zadanie wyjaśniać zainteresowanym na specjalnych spotkaniach, czym jest wirus HIV/ AIDS, w jaki sposób można się nim zarazić i go przenosić oraz jakie są konsekwencje zarażenia się nim ${ }^{36}$.

Biblioteka Xichang jest również odpowiedzialna za organizację sieci międzybibliotecznych i doradztwa w zakresie działalności dla miejskich i wiejskich bibliotek prefektury Liangshan. Na tym poziomie administracyjnym ta książnica ma powiązania biblioteczne z takimi instytucjami naukowymi, jak uniwersytety, szkoły techniczne i szkoły ogólnokształcące. Ze względu na różne zapotrzebowanie i świadczone usługi działalność ta ma dwojaki charakter: miejski i wiejski ${ }^{37}$.

32 http://www.xcslib.org/index.php?c=category\&id=45 [dostęp: 20.05.2019].

33 Rozmowa z kustoszem biblioteki Ma Haiyun...

34 S. Ming, C. Zhong "Liangshan Eagle" sinks claws into drug traffic, 26.06.2006, http:// www.chinadaily.com.cn/cndy/2006-06/26/content_625436.htm [dostęp: 20.05.2019].

35 An Baijie 7th plenary session to set agenda, 11.10.2017, http://www.chinadaily.com.cn/ china/2017-10/11/content_33095203.htm [dostęp: 21.05.2019].

$36 \mathrm{http}: / /$ www.xcslib.org/index.php?c=category\&id=45 [dostęp: 21.05 .2019 ].

37 L. Xianghui, op. cit., s. 145. 
$\mathrm{Na}$ obszarach wiejskich, poza dostarczaniem literatury do tych regionów, działaność biblioteki związana jest również ze szkoleniem personelu i wysyłaniem go na wieś w celach edukacyjnych, związanych z nauką pisania oraz czytania. Biblioteka Xichang odpowiada za zakładanie na wsiach sal do czytania, tak zwanych sal bibliotecznych, w których lokalne społeczeństwo ma dostęp do podręczników nauki języka mandaryńskiego, książek i prasy. Literatura jest dostarczana w sposób regularny w postaci kilkudziesięciu pozycji przywożonych w kartonach przez personel głównej placówki. Po przeczytaniu książek przez lokalną społeczność są one wymieniane pomiędzy wsiami i w sposób skoordynowany dostarczane do czytelników z innych miejscowości. Książki są dowożone także do licznych sierocińców, w których przebywają dzieci z rodzin zakażonych wirusem HIV oraz po prostu porzucone przez rodziców ${ }^{38}$.

Działalność i funkcjonowanie biblioteki są całkowicie uzależnione od decyzji lokalnej administracji samorządowej. Zarząd miasta Xichang jest odpowiedzialny za finanse związane $\mathrm{z}$ istnieniem instytucji i w ostatnim roku wyznaczył budżet placówki na niebagatelną sumę 1,25 miliona juanów ${ }^{39}$. To również z ramienia władz lokalnych są opłacane wszelkie wydatki na utrzymanie biblioteki i jej pracowników, zakup książek i niezbędnego wyposażenia, organizację wydarzeń kulturalnych i pokrycie kosztów związanych z prowadzeniem tej różnorodnej, a społecznie bardzo ważnej działalności, zarówno na terenie biblioteki, jak i poza nią. Równocześnie żaden podmiot fizyczny pozarządowy nie może wspierać finansowo biblioteki bez wcześniejszego pozwolenia władz. Dozwolone są natomiast darowizny od różnych firm, osób prywatnych i placówek edukacyjno-kulturalnych w postaci książek i innych publikacji ${ }^{40}$.

\section{BIBLIOTEKA PROWINCJI SYCZUAN W CHENGDU}

Biblioteka ta powstała w 1912 roku, czyli pierwszym roku istnienia Republiki Chińskiej; znajdowała się w strukturach administracji miejskiej. Jednocześnie od połowy lat 30. podejmowano próby stworzenia biblioteki obejmującej swoim zasięgiem całą prowincję ${ }^{41}$. Biblioteka Prowincji Syczuan została oficjalnie otwarta 10 kwietnia 1940 roku i mogła pomieścić ponad 40 tysięcy książek oraz 150 czytelników. Po utworzeniu Chińskiej Republiki Ludowej w październiku 1949 roku Biblioteka Prowincji Syczuan została przejęta przez Departament Kultury i Edukacji Zachodniego Syczuanu, a jej nazwę zmieniono na Bibliotekę Zachodniego Syczuanu. W 1951 roku nastąpiła ponowna zmiana nazwy placówki, tym razem

\footnotetext{
38 Ibidem.

39 Dla porównania można podać, że chleb lub butelka wody kosztują 2 juany.

40 Rozmowa z kustoszem biblioteki Ma Haiyun...

41 http://www.sclib.org/info.htm?id=1021537174556794 [dostęp: 25.05.2019].
} 
na Ludową Bibliotekę Syczuanu. W roku następnym w wyniku zmian administracyjnych i terytorialnych prowincji Syczuan (łączących cztery dotychczasowe regiony: wschodni, zachodni, północny i południowy) placówka została objęta jurysdykcją Prowincjonalnego Biura Kultury i ponownie zmieniła nazwę na Bibliotekę Prowincji Syczuan ${ }^{42}$.

W ciągu następnych kilkudziesięciu lat Biblioteka Prowincji Syczuan należała do pierwszej dziesiątki bibliotek publicznych w Chinach. Była odpowiedzialna za zbieranie, ochronę, zarządzanie i udostępnianie książek dla całego regionu. Przejęła również istotną funkcję kolekcjonowania starożytnej literatury tybetańskiej, a pracownicy biblioteki często podróżowali w górzyste obszary Chin w celu poszukiwania cennych zabytków piśmienniczych tamtejszej kultury.

Wiążący się z tym gwałtowny wzrost liczby książek i czytelników postawił bibliotekę w obliczu kryzysu lokalowego ze względu na szybko kurczącą się przestrzeń do prowadzenia dotychczasowej działalności ${ }^{43}$. W 2008 roku podjęto zatem decyzję o budowie nowego budynku Biblioteki Prowincji Syczuan. Był to największy projekt kulturalny tej prowincji i miał zakończyć się w 2012 roku, czyli w stulecie rocznicy powstania Biblioteki Syczuan. Prace zostały zapoczątkowane w następnym roku i przebiegały pod bezpośrednim nadzorem lokalnego komitetu Komunistycznej Partii Chin i Rządu Prowincji Syczuan oraz regionalnej grupy partyjnej Departamentu Kultury. Otwarcie nowej placówki zostało opóźnione o kilka lat — nastąpiło oficjalnie dopiero 26 grudnia $2016 \mathrm{roku}^{44}$.

Biblioteka Prowincji Syczuan mieści się w imponującym budynku z mapą prowincji wykutą w marmurowej podłodze holu głównego. Całość składa się z dwóch części: zachodniej i wschodniej, nawiązujących swą konstrukcją do „skarbnic wiedzy” z dynastii Han. Szczyt budynku przypomina natomiast dwa kapelusze doktorskie ${ }^{45}$. Kolekcja biblioteki w 2016 roku zawierała 4,6 miliona książek, w tym 650 tysięcy pozycji starożytnych, 250 tysięcy dokumentów z okresu Republiki Chińskiej i 150 TB zasobów cyfrowych ${ }^{46}$.

Biblioteka ma własny system nabywania książek i innych dokumentów, który koncentruje się głównie na pozycjach związanych z naukami społecznymi i humanistycznymi. Kolekcje są uzupełnianie na podstawie rocznych sprawozdań i statystyk działu czytelnictwa, który w precyzyjny sposób wskazuje trendy czytelników i wynikające z tego największe zapotrzebowanie. Każdego roku placówka otrzymuje od prowincjonalnego Biura Ministerstwa Kultury 16 milionów juanów

${ }^{42} \mathrm{https} / / /$ baike.so.com/doc/6628598-6842399.html [dostęp: 25.05.2019].

43 Rozmowa z pracownikiem biblioteki Xia Xiaojing (przewodnikiem po wystawie „Historia wzlotów i upadków"); badanie własne: 21.05.2019.

44 Rozmowa z Xia Xiaojing (bibliotekarz) i Chen Xiaoyen (kierownik działu zasobów ludzkich); badanie własne: 21.05.2019.

45 http://www.library.sh.cn/Web/news/2015616/n49762435.html [dostęp: 25.05.2019].

46 http://www.sclib.org/index.htm [dostęp: 25.05.2019]. 
na zakup książek chińskich oraz 600 tysięcy juanów na pozycje zagraniczne ${ }^{47}$. Instytucja ta ze względu na promocję i doskonalenie kultury chińskiej, a także potrzebę zaspokojenia narodowych zainteresowań czytelniczych opiera swoje zasoby na rodzimej literaturze kultywującej tradycję i kulturę kraju. Najcenniejszymi posiadanymi przez nią kolekcjami są: odręcznie pisane zwoje piśmiennictwa dynastii Sui (589-619) i Tang (618-907), zbiory poezji wybitnych pisarzy tworzących w czasach dynastii Song (960-1279), Yuan (1279-1368), Ming (1368-1644) oraz Qing (1644-1911), cenne kroniki lokalne prowincji Syczuan, starożytna literatura opisująca tradycyjną medycynę chińską, rękopisy znanych osobistości kultury, a także literatura z okresu istnienia Republiki Chińskiej. Opisywany zbiór najbardziej wartościowych pozycji liczy ponad 700 tysięcy pozycji ${ }^{48}$.

Biblioteka Prowincji Syczuan prowadzi bardzo aktywną działalność kulturalną i pedagogiczną, mającą na celu rozpowszechnienie wiedzy i promocję kultury prowincji i kraju. Jednym z popularnych i odbywających się regularnie co dwa tygodnie wydarzeniem organizowanym przez placówkę jest Salon Czytelniczy Chuantu Chuan tu du shu sha long. Spotkania te są okazją do czytania i zapoznawania się z różnorodną literaturą (w tym klasyki literatury chińskiej) oraz rozmów na tematy przedstawiane podczas spotkania. Tematyka Salonu Czytelniczego jest bardzo rozległa, ale często podnoszone są sprawy rodzinne, związane z wychowaniem dzieci, rodzicielstwem i najważniejszymi wartościami rodziny. Temat wykładów często jest kontynuowany, a spotkania mają charakter cykliczny, zmieniają się natomiast zaproszeni goście, którzy są specjalistami w danej dziedzinie. W 2019 roku odbyło się już 18 spotkań Salonu Czytelniczego Chuantu; 25 maja 2019 roku odbył między innymi 17 Salon Czytelniczy, którego tematyką była edukacja rodzinna. Kurs zorganizowany przy współpracy Biblioteki Prowincji Syczuan i Centrum Rozwoju Młodzieży próbował pokazać, jak ważną rolę odgrywają rodzice w edukacji dziecka, i odpowiedzieć na pytania: skąd pochodzi motywacja do nauki u dzieci, co powinna zrobić rodzina w obliczu egzaminu wstępnego na studia, a także co powinni zrobić najbliżsi w obliczu planowania długoterminowej przyszłości dzieci.

Kolejną formą działalności Biblioteki Prowincji Syczuan, która również odbywa się regularnie w każdy weekend, jest Bashu Forum Ba shu jiang tan. Są to prowadzone zarówno na terenie biblioteki, jak i w innych ośrodkach kulturalnych i mniejszych placówkach bibliotecznych wykłady osób i specjalistów z różnych dziedzin życia. Forum Bashu trwa nieprzerwanie od ponad dziesięciu lat i cieszy się dużym zainteresowaniem publiczności. Jako przykład można tu przytoczyć wykład „Chodzenie po płaskowyżu, pisanie po płaskowyżu”, który odbył się 4 maja 2019 roku. Gościem wykładu była Qiu Shanshan — była dyrektorka kreatywnego studia w oddziale wojskowym w Chengdu. Qiu Shanshan, która przez

\footnotetext{
47 Rozmowa z Xia Xiaojing i Chen Xiaoyen; badanie własne: 21.05.2019.

48 https://baike.so.com/doc/6628598-6842399.html [dostęp: 25.05.2019].
} 
czterdzieści lat pełniła służbę wojskową, opowiadała o swoich doświadczeniach w pracy pisarskiej i przeprowadzaniu wywiadów w Tybecie. Autorka powieści Czekam na ciebie w niebie oraz Wiosenna trawa jest laureatką wielu nagród literackich, takich jak: Nagroda Literacka Chińskiej Armii Wyzwolenia Ludu, Nagroda Literacka Prowincji Syczuan i Nagroda Literatury Ludowej. Niektóre z prac Qiu Shanshan zostały przetłumaczone na język japoński, koreański oraz wietnamski i opublikowane za granica.

Biblioteka Prowincji Syczuan skupia się również na działalności związanej z promowaniem dawnej i współczesnej sztuki. Taki cel i charakter mają cykliczne spotkania organizowane przez Stowarzyszenie Doceniające Sztukę Weekendową. W marcu 2019 roku stowarzyszenie zaprosiło Yang Li — członka Syczuańskiego Stowarzyszenia Tancerzy, którego wykład pod tytułem Uznanie narodowej kultury syczuańskiego tańca ludowego objaśniał znaczenie sztuki tańca ludowego i jego wartości historyczne, przekazywane z pokolenia na pokolenie ${ }^{49}$.

Poza licznymi wykładami i spotkaniami autorskimi biblioteka organizuje także liczne wystawy malarskie, fotograficzne i kaligrafii tradycyjnego pisma chińskiego. W 2018 roku zorganizowano ich aż osiem. Jednym z nich była odbywająca się od 14 sierpnia do 3 września wystawa pod tytułem „Pływające złote światło - krótka historyczna wystawa starożytnych klasyków chińskich”. Wystawa ukazywała kierunki rozwoju starożytnych chińskich książek i miała na celu popularyzację wiedzy na temat sztuki ojczystego piśmiennictwa wśród młodzieży ${ }^{50}$. W 2019 roku została natomiast zorganizowana „Wystawa fotograficzna przyjaźni chińsko-pakistańskiej”. Otwarta była w Sali Gwiazd w głównym gmachu biblioteki od 23 marca do 1 kwietnia 2019 roku; współorganizatorem tego wydarzenia były Biblioteka Prowincji Syczuan wraz z Konsulatem Generalnym Pakistanu w Chengdu.

Placówka prowadzi ponadto działalność poza obrębem swego budynku. Są to liczne zajęcia promujące czytelnictwo w miejskich przedszkolach i szkołach podstawowych, a także w bibliotekach wiejskich w prowincji Syczuan. Zarząd generalny biblioteki ustanowił również pięcioletni plan wybudowania 100 nowych mikrobibliotek w wiejskich obszarach prowincji. Koszt związany z powstaniem tych placówek zostanie w całości pokryty z budżetu Biblioteki Prowincji Syczuan, a powstałe placówki będą stanowić jej oddziały na terenach wiejskich ${ }^{51}$.

$$
* * *
$$

Otwarcie się Chin na świat i wpływ cywilizacji zachodniej spowodował, że biblioteki publiczne stały się ważnymi instytucjami naukowo-informatycznymi, dostępnymi dla szerokiej publiczności. Ostatnie dekady pokazują ważne zmiany

49 Rozmowa z Xia Xiaojing i Chen Xiaoyen...

50 http://www.sclib.org/info.htm?id=1021529998416892 [dostęp: 25.05.2019].

51 Rozmowa z Xia Xiaojing i Chen Xiaoyen... 
zachodzące w ich działalności, funkcji społecznej i zaawansowaniu technologicznym. Budowa nowoczesnego systemu bibliotek publicznych stała się ważną częścią nowego programu Komunistycznej Partii Chin, który przeznacza ogromne środki finansowe na realizacje tego celu.

\section{BIBLIOGRAFIA}

An Baijie 7th plenary session to set agenda, 11.10.2017, http://www.chinadaily.com.cn/china/2017-10/11/ content_33095203.htm [dostęp: 21.05.2019].

Chien Lin S., Libraries and Librarianship in China, Westport 1998.

Dewastowanie zabytków, niszczenie dziet sztuki, terror. 52 lata temu rozpoczęła się Rewolucja Kulturalna w Chinach, 6.02.2018, http://www.national-geographic.pl/historia/50-lat-temu-rozpoczela-sie-rewolucja-kulturalna-w-chinach [dostęp: 20.05.2019].

Man S., Bei S., Bo G., Gang L., Digibook Makerspace in Chinese Public Libraries, 5.03.2014, http:// library.ifla.org/826/1/120-shu-en.pdf [dostęp: 12.03.2019].

Ming S., Zhong C., "Liangshan Eagle" sinks claws into drug traffic, 26.06.2006, http://www.chinadaily.com.cn/cndy/2006-06/26/content_625436.htm [dostęp: 20.05.2019].

Mingrui H., Reading books is just one small part of what this library will offer, 25.09.2017, http:// www.ecns.cn/2017/09-25/274964.shtml [dostęp: 7.03.2019].

Yi Z., History of Library Developments in China, http://library.ifla.org/143/1/164-yi-en.pdf [dostęp: 15.10.2019].

Yongliang L., Zhong hua ren min gong he guo gong gong tu shu guan fa shi yi ji cao zuo shi wu [ang. Public Library Law of the People's Republic of China Interpretation and Operation Practice], China Knowledge Publishing House Pekin 2017.

Wang P., Top 10 largest libraries in China, http://www.chinawhisper.com/top-10-largest-librariesin-china/ [dostęp: 7.03.2019].

Xianghui L., Xi Chang tu shu guang ji tu shu shi ye de li shi hui gu yu xian zhuang [ang. Historical review and current situation of Xichang library and book business], [w:] XiChang wen shi, [ang. History of Xichang] red. Y. Liwei, S. Zaide, Z. Yuanchen, Xichang 1993.

\section{ŹRÓDŁA INTERNETOWE}

http://il.china-embassy.org/eng/whys/whzc/t159977.htm [dostęp: 5.05.2019].

http://narchitects.com/work/shanghai-library/ [dostęp: 7.03.2017].

http://www.ebib.pl/publikacje/matkonf/biblio21/sesja6ref3.pdf [dostęp: 25.05.2019].

http://www.library.sh.cn/Web/news/2015616/n49762435.html [dostęp: 25.05.2019].

http://news.voc.com.cn/article/201906/201906111645587066.html [dostęp: 10.11.2019].

http://www.nlc.cn/newen/ [dostęp: 5.05.2019].

http://www.sbp.pl/artykul/?cid=9592\&prev=100 [dostęp: 25.05.2019].

http://www.sclib.org/index.htm [dostęp: 25.05.2019].

http://www.sclib.org/info.htm?id=1021529998416892 [dostęp: 25.05.2019].

http://www.sclib.org/info.htm?id=1021537174556794 [dostęp: 25.05 .2019$]$ ].

http://www.xcslib.org/index.php?c=category\&id=23 [dostęp: 20.05.2019].

http://www.xcslib.org/index.php?c=category\&id=45 [dostęp: 20.05.2019].

http://www.sclib.org/list.htm?m=1521488440060361\&c=1521488440060364 [dostęp: 25.05.2019].

https://baike.so.com/doc/6628598-6842399.html [dostęp: 25.05.2019].

https://en.wikipedia.org/wiki/Century_Park_(Shanghai) [dostęp: 7.03.2019].

(C) for this edition by CNS 
https://pl.wikipedia.org/wiki/Chińska_wojna_domowa [dostęp: 20.05.2019]. https://wenku.baidu.com/view/ff792d6b58fafab069dc0269.html [dostęp: 5.06.2019]. https://www.chinahighlights.com/travelguide/china-national-day.htm [dostęp: 20.05.2019].

DAWID SULIKOWSKI

THE CULTURAL AND EDUCATIONAL ACTIVITIES

OF CHINESE PUBLIC LIBRARIES AS EXEMPLIFIED BY LIBRARIES

IN SHANGHAI, XICHANG AND CHENGDU

\begin{abstract}
Summary
The aim of the article is to present to Polish readers a general picture of the cultural and educational activities of public libraries in the People's Republic of China. The author uses as his examples the Eastern Branch of the Shanghai Public Library, Public Library in Xichang and the Library of the Sichuan Province in Chengdu. The main sources of information for the article are the websites of the analysed libraries, books and other publications devoted to librarianship in China as well as individual interviews with library staff members and curators. The author examines the dynamic development of libraries in China, their new functions and various forms of activity.
\end{abstract}

KEY WORDS: public libraries, China, Shanghai, Xichang, Chengdu 